\title{
Dorota Rybarkiewicz
}

Uniwersytet Łódzki

\section{DIALETEIZM PUNKTEM SPOTKANIA BOGA RELIGII Z BOGIEM FILOZOFÓW? UWA G KLKA: WIĘCEJ PYTAŃ NIŻ ODPOWIEDZI}

Chociaż trudno nie zgodzić się ze stwierdzeniem Andrzeja Grzegorczyka, że „rzeczywistość boska może nie być opisywalna w strukturach naszego języka" (2010, s. 82), to trudno też zaprzeczyć, że tak właśnie jest opisywana. Siłą rzeczy cały poniższy wywód o ewentualnej dialeteiczności boskich przymiotów lub działań ma z konieczności charakter językowy, ma zatem dwoistą naturę opisaną powyżej: jest jedynym sposobem przybliżenia tej rzeczywistości, lecz dalekim od adekwatności. Jak poniżej zobaczymy, owa dualność stała się również argumentem na rzecz głównej tezy dialeteizmu.

Dialeteja to zdanie $A$ takie, że zarówno ono, jak i jego negacja są prawdziwe, przy czym można tu mówić nie tylko o zdaniu, lecz także o dowolnym nośniku prawdy: sądzie, stwierdzeniu, itp. Natomiast dialeteizm to pogląd, według którego istnieją dialeteje ${ }^{1}$. Zauważmy, że w definicji dialetei nowa podwójna wartość logiczna (glut) zdefiniowana jest wyłącznie za pomocą pojęć semantycznych. Zatem według dialeteizmu istnieją prawdziwe sprzeczności, co zawiesza przynajmniej czasami działanie prawa niesprzeczności, które w głównym nurcie tradycji wywodzącej się od Arystotelesa było uznawane za niepodważalne:

Są filozofowie , którzy, jak już powiedzieliśmy, twierdza, że ta sama rzecz może być i nie być oraz że można tak sądzić. [...] My natomiast zajęliśmy takie stanowisko, iż jest niemożliwe, ażeby jakaś rzecz równocześnie była i nie była, i w ten sposób wykazaliśmy, że zasada ta jest najpewniejsza ze wszystkich (Arystoteles 2002, 1006a).

Arystoteles pisze dalej, że zasada niesprzeczności jest również najbardziej oczywista ze wszystkich. Zasada ta wyrażana była rozmaicie, ale najczęściej przyjmuje postać semantyczną: dla dowolnego $A$ jest niemożliwe, aby zarówno $A$, jak i nie- $A$ były prawdziwe.

1 Por. (Priest 1985/1986). 
Dialeteizm jako pogląd znany był już w starożytności, ale sam termin wprowadzili na arenę logiki i filozofii Graham Priest i Richard Routley (Sylvan) w 1981 r. (por. Priest 2018). W artykule Why It's Irrational to Believe in Consistency, Priest wyraźnie stwierdza, że sprzeczność niekoniecznie jest błędem, a nawet może być zaleta, przy czym pojęcie sprzeczności, takie jakie on sam najczęściej formułuje, odwołuje się do formy, do syntaksy. Co więcej, próbuje on uzasadnić, że nie należy traktować niesprzeczności jako warunku sine qua non racjonalności. Stawia nawet silniejszą tezę: że to bycie niesprzecznym jest nieracjonalne (Priest 2001, s. 289), uchylając tym samym furtkę dla konkretnego stanowiska wobec sprzeczności pojawiających się w opisach atrybutów boskich.

Chociaż główną motywacją do przyjęcia dialeteizmu nie tylko w logice, ale i w filozofii sa paradoksy (paradoks kłamcy odgrywa tutaj sztandarową rolę), to kłopotliwa konstatacja, że pewne zdania mogą być zarazem prawdziwe i fałszywe, pojawiła się także w kontekście rozważań teologicznych. Szczególnie dwa atrybuty przypisywane Bogu: wszechmoc i wszechwiedza, prowadzą do zarzutów, które w swej formie przypominają paradoksy kłamcy albo paradoksy teorii zbiorów. Wraz z pojawieniem się logik parakonsystentnych oraz logiki paradoksu (oraz wraz z próbą wskrzeszenia poglądów dialeteicznych) powstało też pytanie, czy dialeteizm z narzędziami odpowiedniej dla niego logiki może przyczynić się do rozwiązania problemów wynikających ze sprzeczności w kontekście teologii. Również ateiści, dla których jawna sprzeczność boskich atrybutów miałaby być dowodem nieistnienia Boga, mogą być zainteresowani ewentualnym dialeteicznym rozstrzygnięciem sprawy.

Zagadnienie sprzeczności w odniesieniu do Boga ma wiele aspektów. Może dotyczyć pytania o to, czy działania Boga mogą prowadzić do sprzeczności; może też dotykać kwestii charakteru samych przymiotów Boga. Ponadto w sposób oczywisty z pojęciem sprzeczności łączą się nieodwołalnie logika i jej prawa. I tutaj pojawiają się różne ujęcia samego przedmiotu, jak np. dwa wyraźnie zarysowane, przyznające logice bądź status obiektywny, gdy prawa są odkrywane - czasami uważa się, że są „osadzone" w umyśle Boga - bądź subiektywny, kiedy jej prawa są konstruowane lub „osadzone” w naszych umysłach (według niektórych być może przez Boga).

Przekonanie o tym, że Bóg może wywoływać sprzeczne stany rzeczy i że Jego poznaniu dostępne są prawdziwe sprzeczności, pojawiało się niejednokrotnie $\mathrm{w}$ refleksji filozoficznej i teologicznej. Ale już np. scholastycy, jak św. Tomasz z Akwinu i William Ockham, twierdzili, że nic Boga nie ogranicza - jedynie to, co pociąga za sobą sprzeczność.

Sam twórca nurtu dialetycznego, Priest, z pewną satysfakcją przytacza fragmenty dzieł teologicznych, w których wykazuje się sprzeczność 
Boga. Zwolennikiem dialeteizmu według kryteriów byłby według niego np. Piotr Damiani, który w De divina omnipotentia przedstawia problem (paradoks) wszechmocy boskiej. Twierdzi w tym dziele - jak podaje wielu jego interpretatorów - że wszechmoc Boga zawiesza prawa logiki łącznie z prawem niesprzeczności, gdyż „moc Boża często obala zbrojne sylogizmy" (Damiani 2008, s. 79). Podobnie Mikołaj Kuzańczyk w De docta ignorantia głosi, że Bóg jest coincidentia oppositorum: jako byt prawdziwie nieskończony ma wszelkie własności, także sprzeczne:

Oprócz Boga nic nie może istnieć. Zatem istota Boga przenika wszystko. Bo tak jak żadne stworzenie nie może uciec od swojej własnej istoty, nie może też uciec od Twojej istoty, która wszystkim bytom nadaje istotę bytu. I tak Bóg porusza się we wszystkim, co się porusza i odpoczywa we wszystkim, co odpoczywa. A ponieważ niektóre byty poruszają się a inne stoją to Bóg porusza się i stoi w tym samym czasie. Jako, że jeśli zarówno ruch, jak i spoczynek realizują się w tym samym czasie w różnych bytach i jeśli nic nie może istnieć poza Bogiem, ani żaden ruch ani żaden spoczynek, zatem Bóg jest w pełni obecny w tych wszystkich rzeczach i w każdej z nich w tym samym czasie. A jednak Bóg ani się nie porusza ani nie spoczywa, bo jest ponad wszystkim i wolny od wszystkiego, co może być postrzegane lub nazwane. Zatem Bóg stoi i się porusza i nie stoi i się nie porusza w tym samym czasie ([1453] 2016, s. 41-42).

Sprzeczność oznacza dychotomię; jest logiczna, gdy ten sam język pozwala na wywiedzenie danej formuły i odrzucenie jej, czyli technicznie rzecz ujmując, gdy sprzeczność jest koniunkcją zdania i jego negacji. Czy zatem niektóre sprzeczności występujące w tekstach opisujących Boga należy zaakceptować jako prawdziwe $\mathrm{w}$ dosłownym sensie (dialeteiczne podejście do sprzeczności)? Czy też lepszym rozwiązaniem jest szukanie dla nich innych interpretacji, zachowując założenie, że sprzeczność nie może być prawdziwa, i zachowując tym samym prawo niesprzeczności (ortodoksyjne podejście do sprzeczności)? Zauważmy, że jeśli zrezygnujemy z podstawy, jaką jest zasada niesprzeczności, to pozostanie kwestią nierozstrzygnięta, które z powyższych dwóch podejść jest bardziej uzasadnione (filozoficznie, teologicznie, logicznie).

Pojawia się także pytanie o tzw. mocny dialeteizm w wersji ontologicznej: czy to przełożenie rzeczywistości (Boga) na kategorie języka dostępne człowiekowi rodzi sprzeczność, czy też sama istota tej rzeczywistości jest sprzeczna, jak „radykalna asymetria ontologiczna” (Petrocchi 2011, s. 10), obecna np. w tajemnicy Verbum caro factum est: Verbum jest nieskończone, "ciało" jest skończone, Verbum jest odwieczne, "ciało" żyje w czasie, Verbum jest niezmienne, "ciało" nieustannie się staje. Jest to zarazem pytanie o to, czy opis natury boskiej i doświadczenia Boga podpada pod kryterium prawdziwości rozumianej tak jak w korespondencyjnej teorii prawdy, gdzie zakłada się pewną relację odpowiedniości między 
językiem a rzeczywistością. Zatem czy istnieje taka relacja między językiem opisującym Boga a Nim samym? Jeśli tak, to czy z tego, że opis zawiera sprzeczności, wynika, że i Bóg jest sprzeczny, a więc sprzeczna jest Jego wewnętrzna natura, a język jedynie „podąża” za nią wiernie? Czy to by oznaczało, że sprzeczność syntaktyczna bądź semantyczna implikuje ontologiczną? I czy, gdy się na to przystanie, należy tym samym dojść do wniosku, że taki bóg nie może istnieć, a zatem nie ma Boga?

Czy może mamy do czynienia z błędem ekwiwokacji, który, jak wiemy, prowadzić może do sprzeczności? Na jej ślad wskazał Geach ${ }^{2}$ w samym pojęciu wszechmocy. Zauważył on mianowicie, że język angielski dysponuje dwoma terminami: jednym, używanym w Kościele, „almighty” (co oznacza władzę nad wszystkimi rzeczami), oraz drugim, stosowanym w dyskursie filozoficznym i teologicznym - „omnipotent” (możność uczynienia wszystkiego). Dzięki temu jego język ojczysty, jak twierdzi Geach, jest w szczęśliwym położeniu, ponieważ pozwala na uniknięcie tego błędu i dzięki temu nie wikła się w sprzeczność (przynajmniej jeśli chodzi o boską wszechmoc).

A może sprzeczności pojawiające się w opisie Boga są wynikiem katachrezy, o której pisał M. Black odnośnie do pewnej funkcji metafor, która polega na tym, że po dostrzeżeniu analogii za pomocą znanych terminów próbuje się coś powiedzieć o nowych i nieopisanych dotychczas zjawiskach albo o bardziej abstrakcyjnych pojęciach? Metaforyczne użycie słów służy wówczas do wypełniania luk semantycznych, lecz jednocześnie niesie za sobą metaforyczny konflikt, pod pewnymi względami bowiem jest tak, jak metafora głosi, lecz pod innymi tak nie jest. Dla ilustracji: kiedy mówimy, że Bóg jest ojcem, przypisujemy Mu pewne cechy ojca (np. opiekuńczość), lecz innych już nie (np. bycie mężem mamy).

Ponadto w rozważaniach Priesta opisana jest jeszcze jedna płaszczyzna zderzenia (wskazana na samym początku), którą można by tu nazwać meta-dialeteizmem. Jest to sprzeczność, która zdaniem Priesta pojawia się na tzw. granicach myśli, czyli granicach konceptualnych, gdy z jednej strony np. uważamy, że nie da się ani poznać, ani opisać Boga, jako że jest On transcendentny, ale z drugiej właśnie usiłujemy Go poznać i ująć Jego cechy za pomocą znanych wyrażeń językowych. Mówiąc cokolwiek o Bogu, który znajduje się poza granicą wyrażalności (expressibility), balansujemy na granicy, a nawet, można powiedzieć, jesteśmy niespójni, gdyż, jak pisze Priest, „granice myśli są granicami, których nie można przekroczyć, a jednak je przekraczamy" (1995, s. 3). Popadamy tym samym w dialeteiczny konflikt. I tak przekonanie Mikołaja Kuzańczyka wyrażone w De docta ignorantia, że Boga nie da się pojąć, jest jednocześnie

2 Por. (Geach 1977, s. 3-28). 
stwierdzeniem o Bogu czegoś, co się da pojąć. Nie jesteśmy w stanie wyrazić (słowami) ostatecznej natury boskiej, ponieważ jakakolwiek jej charakterystyka musi posłużyć się pojęciami, a wszelka konceptualizacja w jakimś stopniu fałszuje obraz Tego , którego usiłuje przedstawić. Zarazem jednak wypowiadając powyższe zdanie, jesteśmy w stanie powiedzieć coś o ostatecznej naturze boskiej. Zatem można powiedzieć, że natura Boga jednocześnie daje się i nie daje się wyrazić. Używając terminologii Priesta, można powiedzieć, że dochodzimy do granicy niewyrażalności (następuje moment transcendencji), lecz jednocześnie stwierdzamy to, podając w ten sposób istotę sprawy (Priest nazywa ten moment "domknięciem", ,closure schema"). Stanowi to jego zdaniem oczywisty paradoks. Frederick Kroon zauważa, że w tym miejscu wywód Priesta dotyczący przekraczania granic niewyrażalności oparty jest na błędnej teorii substancji, jednak nie wyjaśnia tego szerzej. Trudno więc stwierdzić, czy też jest tak w przypadku, gdy mowa nie o substancji, lecz Bogu (Kroon 2001).

Za myślą Kuzańczyka, że Bóg jest coincidentia oppositorum, idzie wielu myślicieli chrześcijańskich. Również w tym kierunku zdaje się podążać Chiara Lubich³, opisując swoje doświadczenie poznawania Boga:

Jezus opuszczony jest marnością i jest Słowem; jest tym, co przemija i tym, co pozostaje, gdyż jest Bogiem-Człowiekiem i jako człowiek jest całkowicie stworzeniem, które jest marnością nad marnościami, a jako Bóg jest ogniem, który spala w sobie wszystkie rzeczy, całą nicość [...] wszelkie marności stały się $\operatorname{Nim}[\ldots](2017$, s. 55-56).

Jezus opuszczony jest, ponieważ nie jest (2017, s. 61).

Aby objąć w sobie Wszystko, trzeba być nicością [...] (2017, s. 64) .

Jednak, jak się wydaje, zachodzi pewna różnica między opisem Mikołaja Kuzańczyka a tym, o czym mówią teksty Lubich. Wywód tego pierwszego ma charakter logiczny - przedstawia rozumowanie, na podstawie którego mamy prawo sądzić o sprzecznej naturze Boga. Tymczasem Lubich zdaje się cieszyć specjalnym epistemologicznym statusem osoby, która doświadczyła mistycznego spotkania z Nim. Jej wiarygodność pochodzi nie stąd, że po prostu uchwyciła ona dzięki temu istotę Boga,

${ }^{3}$ Chiara Lubich (1920-2009) zapoczątkowała życie charyzmatem jedności nazywanym ruchem Focolari. Otrzymała 14 doktoratów honoris causa: z nauk społecznych (KUL 1996), z teologii (Filipiny i Tajwan 1997, Słowacja 2003), z komunikacji społecznej (Tajlandia 1997), z nauk humanistycznych (USA 1997), z filozofii (Meksyk 1997), interdyscyplinarny (Argentyna 1998), z religioznawstwa (Brazylia 1998), z ekonomii (Brazylia 1998, Włochy 1999), z psychologii (Malta 1999), pedagogiki (USA 2000) oraz teologii życia konsekrowanego (Rzym 2004). 
ale $\mathrm{z}$ tego, że poznanie, jakie jej było dane, jest bezpośrednie, pozapojęciowe i właśnie trudne do wyrażenia. W pewnym sensie przypomina to opis podróży do miejsc zupełnie różnych od znanych zakątków świata. Z konieczności zawiera on wiele porównań i metafor, ponieważ brakuje odpowiednich słów do wyrażenia tego, co się poznało. Zatem czy sprzeczność zawarta w takich tekstach miałaby charakter metafory i stanowiła przypadek szczególnej katachrezy? W takim razie sprzeczność nie miałaby charakteru logicznego.

W dyskusji nad tym, czy Boże działania moga generować sprzeczność, traktuje się różne przymioty Boga jako równorzędne. Wydaje się jednak, że wobec „szalonej” miłości Boga do człowieka inne jego cechy jakby właśnie tej się podporządkowywały. Już pierwszy przejaw tej miłości, czyli przyjęcie ciała z Maryi Dziewicy, czyli to, że Jezus jest jednocześnie Bogiem i człowiekiem, burzy porządek rzeczy. Dalej jest już tylko gorzej, jak bowiem pogodzić objawienie się wszechmocy Jezusa, gdy uzdrawia, wskrzesza zmarłych i chodzi po wodzie, z Jego oczywistą bezsilnością wobec oprawców i śmierci w męczarniach, kiedy to z ludzkiego punktu widzenia, jeśli był wszechmocny, właśnie wtedy powinien tą wszechmoc okazać? I my dzisiaj możemy powtórzyć za apostołami, że nie tak sobie wyobrażaliśmy koniec Boga na ziemi. Jeśli pozostał wszechmocny do końca, a nic nie uczynił, aby zejść z krzyża, do czego był szyderczo zachęcany, to chętnie odmówimy Mu logiki i racjonalności wobec takiego (nie)działania. Czai się tu pokusa, aby odmówić Mu także wszechmocy i zaprzeczyć Jego boskości, co też wielu uczyniło. Zarazem jednak świadkowie tego, że zmartwychwstał, nie mogli Mu wszechmocy odmówić i tym samym uznali Go za Boga. Ale jak wówczas zrozumieć to, na co Jezus się zdecydował, w świetle przyjętych założeń?

Jaka zatem może być logika Boga szalonego z miłości? I jak tę logikę odnieść chociażby do słów Jana Łukasiewicza, który odkrywając prawa logiki, ma przekonanie, że:

Nic w niej zmienić nie mogę, nic sam dowolnie nie tworzę, lecz w wytężonej pracy odkrywam w niej tylko coraz to nowe szczegóły, zdobywając prawdy niewzruszone i wieczne. Gdzie jest i czym jest ta idealna konstrukcja? Filozof wierzący powiedziałby, że jest w Bogu i jest myślą Jego (1961, s. 219).

Czy Bóg w porywie miłości zmienia myśl swoją „potężną niesłychanie zwartą i niezmiernie odporną konstrukcję?" (Łukasiewicz 1961, s. 219). Czy też myśl ta pozostaje niezmienna, a jedynie my, poznając jej fragmenty, nie umiemy jej złożyć w logiczną całość? Zauważmy, że przy ocenie tego, czy postępowanie danej osoby jest spójne (niesprzeczne), czy niespójne (sprzeczne), przypisuje się tej osobie określone założenia 
(przekonania, motywacje) na zasadzie analogii do ogólnie przyjętych (własnych, najbardziej prawdopodobnych lub najczęstszych) powodów podjęcia działania. Tymczasem: „[M]yśli moje nie są waszymi myślami”, mówi sam Bóg przez proroka Izajasza (Iz 55:8).

Wydaje się, że właśnie ta różnica na poziomie przyjętych pierwotnie założeń, pewnych bazowych przekonań (myśli), która zachodzi między nami a Bogiem, oraz zwłaszcza to, że nie znamy tych boskich myśli, powoduje, że odbieramy Jego działania i cechy jako co najmniej niezrozumiałe. W ocenie Jego działania przypisujemy $\mathrm{Mu}$ cechy ludzkie i najczęściej zupełnie pomijamy miłość jako Jego siłę napędowa także zapominając, że szanuje naszą wolność. Co więcej, zdaje się, że podobnie jak Priest, a za nim zwolennicy dialeteizmu, widząc, że schemat domknięcia prowadzi do absurdu (do sprzeczności) na bazie przyjętych przesłanek (nawet całkiem prawdopodobnych), dochodzimy do wniosku, że jest to potwierdzeniem słuszności teorii dialetycznej. Krótko mówiąc, przypisujemy Bogu własne motywacje i na tej podstawie wysnuwamy "dowód" na to, że Jego działania, a może nawet natura, są absurdalne, sprzeczne (czy nawet szalone). Tymczasem przeoczyć można naturalne pytanie o to, dlaczego pojawienie się sprzeczności nie prowadzi do podważenia przesłanek. Priest zdaje się zatrzymywać w swym wywodzie właśnie na tym etapie: tuż przed zadaniem takiego pytania. Czyżby również ci, którzy upatrują sprzeczności w boskim działaniu i boskich przymiotach, mogli być nazwani dialeteistami?

Można też próbować wyjaśnić przyczynę pojawiania się sprzeczności w opisach Boga, przywołując ideę, która stoi za ontologią dymensjonalną Victora Frankla. Frankl formułuje definicję człowieka, traktowanego jako jedność pomimo różnorodności psychologiczno-biologicznej, używając pojęcia rzutowania. Za jego pomocą wyrazić można pierwsze prawo ontologii dymensjonalnej: ,jeden i ten sam przedmiot rzutowany ze swego wymiaru na inne, niższe wymiary, odbija się $w$ ten sposób, że jego dwa odbicia wzajemnie sobie przeczą" (Frankl 2010, s. 36). Frankl jako ilustrację podaje odwzorowanie trójwymiarowej szklanki na płaszczyźnie dwuwymiarowej w dwóch rzutach: poziomym i pionowym. Za każdym razem uzyskamy zupełnie odmienny obraz: raz koła, raz prostokąta. "Czyż sprzeczność między kołem i prostokątem nie stoi w sprzeczności z faktem, że chodzi tu o rzuty jednego i tego samego cylindra?" - zauważa autor (Frankl 2010, s. 38). Drugie prawo tej ontologii sformułowane przez Frankla będzie dla naszego wywodu jeszcze bardziej przydatne: "odbicia rzutowanych na niższy wymiar przedmiotów są wieloznaczne". To znaczy, że patrząc np. na koło, możemy uznać, że odwzorowana bryła to kula, cylinder (albo stożek). Nie mamy wystarczających danych, aby mieć pewność, która z nich została rzutowana. 

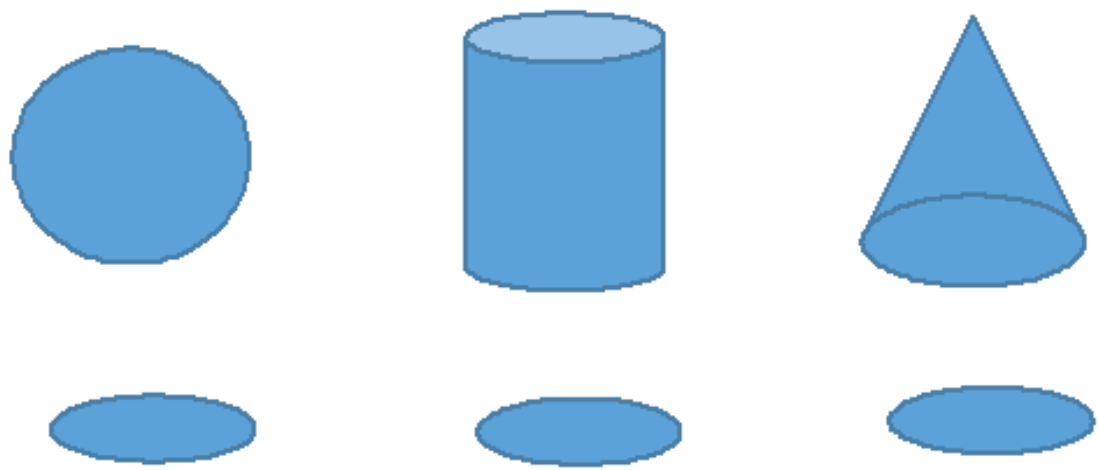

Rysunek 1

Źródło: (Frankl 2010, s. 37)

Być może wszystko to, co możemy powiedzieć o Bogu, ma charakter dymensjonalny, tylko wieloznaczność odbić rzutowanych na niższy wymiar (czyli na nas) przedmiotów z wyższych wymiarów (w tym wypadku Boga) powoduje sprzeczność (bądź wykluczanie się).

Być może jest tak, że przekonanie, że atrybuty Boga są wzajemnie spójne, powinno wypływać (także) z wiary (opartej chociażby na zdaniu: „Każde królestwo wewnętrznie skłócone pustoszeje i dom na dom się wali" [Łk 11:17]), a nie być wynikiem (jedynie) rozumowania i racjonalnych argumentów. Wiara, jak wiemy, sprowadza się do aktu woli i wyboru. Paradoksalnie taki postulat wpisywałby się w podejście Priesta, który przy okazji analizy siedmiu argumentów Arystotelesa na rzecz zasady niesprzeczności podważa jakąkolwiek oczywistość tej zasady. Podaje trzy powody swych wątpliwości. Po pierwsze, skoro Arystoteles uważa, że nic nie jest bardziej pewne i epistemicznie podstawowe niż to, że sprzeczność nie może być prawdziwa, to dlaczego Stagiryta podaje argumenty, że tak jest. Jest to według Priesta podejrzane, jako że nikt nie stara się uzasadniać czegoś, co jest naprawdę oczywiste. Po drugie, jeżeli to prawo jest tak oczywiste, jak twierdzi Arystoteles, to dlaczego nie było oczywiste dla tych, których Arystoteles atakował. Po trzecie, Priest stwierdza, że najważniejszy argument Arystotelesa jest szczególnie poplątany a pozostałe są zaledwie luźno rzuconymi uwagami (Priest 1998). I choć inni komentatorzy tekstu filozofa zawsze uznawali jego wniosek za poprawny, Priest tego nie czyni. Sugeruje tym samym, że za wyborem tejże zasady stoi wiara (może nawet jedynie wiara w autorytet Arystotelesa).

Jednak pomimo wywodów Priesta zasada niesprzeczności traktowana jest jako pewna kotwica epistemologiczna, jako fundament, na którym wznosi się gmach wiedzy. Jak słusznie zauważa Kroon, Priest zdaje się 
zmieniać ten fundament, podważając przekonanie o konieczności stosowania tej zasady w sposób nadrzędny i wskazując na takiego kandydata na ów fundament, który tradycyjnie traktowany jest jak ruchome piaski. Dlatego natrafienie na sprzeczne zdanie (a nawet stan rzeczy) nie musi być dla Priesta powodem, aby odrzucić takie zdanie (stan rzeczy), lecz może stanowić potwierdzenie słuszności dialeteizmu. Oczywiście można w tym miejscu powtórzyć komentarz Tadeusza Szubki ${ }^{4}$, że nie można stąd, że sprzeczność się pojawia, wysnuć wniosku, że jest prawdziwa. Kiedy zabraknie przekonania o nienaruszalności zasady niesprzeczności, tym samym zabraknie dna, od którego można się odbić, jako ostatecznej nieprzekraczalnej granicy bez względu na to, czy nasze rozważania dotyczą bliskiej nam rzeczywistości, czy transcendentnego Boga.

Bez względu na nasz stosunek do dialeteizmu pojęcie Boga wydaje się niespójne. Niemniej dostrzeżenie tego nie jest tożsame $\mathrm{z}$ ateizmem, tak jak spójność pojęcia Boga nie musi cechować teisty. Jak zatem traktować paradoksalność tekstów niektórych mistyków?

Już dyskusje filozofów nad Parmenidesem, który, jak wielu badaczy sądzi, przypisywał Jednemu własności wykluczające, a nawet sprzeczne, a także nad Plotynem, według którego Jedno było niczym i wszystkim zarazem, pokazały, jakie są możliwe stanowiska wobec wyłaniających się aporii. Jedni bowiem wykazywali, że sprzeczności są pozorne. Inni, biorąc je na serio, dochodzili do wniosku, że Jedno „przekracza zakres dyskursu respektującego zasadę sprzeczności" (Poczobut 2000, s. 29). Byli też tacy, którzy uznawali pojawiające się niespójności (sprzeczności) za przejaw owej niewyrażalności, przed którą stajemy, mówiąc o Jednym. W końcu, ci, którzy byliby zwolennikami współczesnego (mocnego) dialeteizmu, chcieliby uznać Jedno za egzemplifikację obiektu sprzecznego.

Ponownie nasuwają się wobec tego pytania postawione m.in. przez Jana Woleńskiego: „czy Bóg jest przedmiotem wiedzy czy wiary, czy też jednej i drugiej i co to znaczy, że możemy racjonalnie dyskutować o istnieniu takiego Absolutu?" (Woleński 2005, s. 167). Nie wydaje się, aby dialeteizm jako pogląd zmienił zasadniczo naszą wiedzę na ten temat. Pozostajemy zatem w paradygmacie scharakteryzowanym zwięźle przez Ryszarda Kleszcza, który pisał, że „o Bogu nie daje się w pełni i adekwatnie mówić, posługując się narzędziami, którymi, jako ludzie, dysponujemy" (2012, s. 51), co nie wyklucza możliwości powiedzenia o Bogu czegoś ważnego w dostępnym nam języku. Słuszny też wydaje się jego postulat, aby nasze mówienie o Bogu wiązało się „,z przyjęciem logiki nie generującej sprzeczności" (Kleszcz 2012, s. 51).

${ }^{4}$ Por. (Szubka 1997). 


\section{Bibliografia}

Arystoteles (2002), Metafizyka, Wydawnictwo Naukowe PWN, Warszawa.

Biblia Tysiaclecia (2012), Pallotinum, Poznań.

Damiani P. (2008), O wszechmocy Bożej, Wydawnictwo Marek Derewecki, Kęty.

Frankl V.E. (2010), Wola sensu, Wydawnictwo Czarna Owca, Warszawa.

Geach P.T. (1977), Providence and Evil, Cambridge University Press, Cambridge.

Grzegorczyk A. (2010), Ani na górze, ani w Jerozolimie..., ale w duchu i prawdzie. Podstawy metodycznej myśli religijnej, „Przegląd Filozoficzny. Nowa Seria” 19, 1(73), s. 79-88.

Kleszcz R. (2012), Logika, wszechmoc, Bóg, „Filo-Sofija” 19(4), s. 37-52.

Kroon F. (2001), Beyond Belief? A Critical Study of Graham Priest's Beyond the Limits of Thought, „Theoria" 87, s. 48-61.

Kuzańczyk M. [1440] (1997), O oświeconej niewiedzy (De docta ignorantia), wstęp A. Kijewska, Znak, Kraków.

Kuzańczyk M. [1453] (2016), Vision of God. (De Visione Dei), Cosimo Classics, New York.

Lubich C. (2017), Jezus opuszczony, Fundacja Mariapoli, Warszawa.

Łukasiewicz J. (1961), W obronie logistyki, [w:] idem, Z zagadnień logiki i filozofii, PWN, Warszawa, s. 211.

Petrocchi G. (2011), Wskazania dla maryjnego profilu nowej ewangelizacji, „Gen's” 4, s. 9-14.

Poczobut R. (2000), Spór o zasade niesprzeczności, Towarzystwo Naukowe KUL, Lublin.

Priest G. (1985/1986), Contradiction, Belief and Rationality, „Proceedings of the Aristotelian Society. New Series" 86, s. 99-116.

Priest G. (1995), Beyond the Limits of Thought, Clarendon Press, Oxford.

Priest G. (1998), To Be and Not to Be - That Is the Answer: On Aristotle on the Law of Non-Contradiction, "Logical Analysis and History of Philosophy” 1, s. 91-130.

Priest G. (2001), Why It's Irrational to Believe in Consistency, [w:] B. Brogaard, B. Smith (red.), Rationality and Irrationality, Obvahpt, Vienna, s. 284-293.

Priest G. (2018), Dialetheism, Stanford Encyclopedia of Philosophy, https://plato.stanford. edu/entries/dialetheism/ (dostęp: 23.04.2020).

Szubka T. (1997), O paradoksalnej naturze granic myśli, "Znak” 49(2), s. 133-139.

Woleński J. (2005), O jakim Bogu mowa? „Diametros” 4, s. 159-175.

Streszczenie: Dialeteizm punktem spotkania Boga religii z Bogiem filozofów? Uwag kilka: więcej pytań niż odpowiedzi

W artykule poruszona jest kwestia dialeteiczności paradoksów pojawiających się w rozważaniach teologicznych szczególnie dotyczących działania i atrybutów Boga. Zwolennicy dialeteizmu traktują fragmenty dzieł teologicznych, w których wykazuje się sprzeczność Boga, jako argumenty na rzecz swego stanowiska. Co więcej, przyjęcie sprzeczność w ramach $\mathrm{tzw}$. mocnego dialeteizmu prowadzi do stwierdzenia, że sama rzeczywistość Boga jest sprzeczna, co z kolei rodzi pytanie, czy opis Boga podpada pod klasyczne kryterium prawdziwości. Jeśli za dialeteistami zrezygnujemy z zasady niesprzeczności jako podstawy, to nie można rozstrzygnąć, które stanowisko jest bardziej uzasadnione. Zamiast dialeteicznego rozwiązania, przedstawione są niektóre inne możliwe powody 
pojawienia się sprzeczności: ekwiwokacja, katachreza i przekraczanie granicy myśli. Najbardziej racjonalne podejście do sprzeczności pojawiających się w opisie Boga wydaje się zakładać logikę niegenerującą sprzeczności.

Słowa kluczowe: dialeteizm, sprzeczność, atrybuty boskie, coincidentia oppositorum, ontologia dymensjonalna

Summary: Is Dialetheism Where God of Religion and God of Philosophers Meet? More Questions than Answers

The article is devoted to the question if paradoxes concerning actions and attributes of God can be solved in dialetheists' manner. For the adherents of dialetheism theological texts where the contradictory nature of God is shown constitute the proof of their main thesis. Moreover, in one version of dialetheism the paradoxes imply that the very reality of God is inconsistent. This gives rise to the question if the classical criteria of truth apply to God. If one undermines the law of non-contradiction, the possibility to justify one's stance is seriously reduced. In fact there are other possible causes of contradiction: equivocation, catachresis, crossing the limits of thought. As it seems, the most rational approach to inconsistency appearing in the description of God is to presume the logic that does not generate contradiction.

Keywords: dialetheism, contradiction, God's attributes, coincidentia oppositorum, dimensional ontology 